\title{
Major Socio-Political Factors that Impact on the Changing Role, Perception and Image of Imams among Dutch-Turkish Muslims
}

\author{
Ömer Faruk Gürlesin \\ Islam Kennis Centrum, Laan op Zuid 129, 3071 AA Rotterdam, The Netherlands; \\ o.f.gurlesin@umail.leidenuniv.nl
}

Received: 23 April 2019; Accepted: 19 June 2019; Published: 26 June 2019

\begin{abstract}
Public debates in the Netherlands assume there is an inherent tension between the traditional task of the imam and his tasks in the secularized Dutch society. Studies of the effect of age and generation on religiosity report that intense religious changes are taking place among second-generation migrants. But the direction of this change is interpreted differently by scholars. A majority of scholars indicate that second-generation migrants consider themselves more 'Muslim' and are more concerned about the traditional sources of religious authority. Other studies report that there is an ongoing pattern of secularization among Muslims in Europe and that second-generation migrants consider themselves less concerned about the traditional and popular sources of religious leadership and authority. In relation to the findings of my PhD study, in this contribution, I elaborate on several factors to shed some light on the possible reasons behind these different findings. These factors are, in turn, the lack of language skills and knowledge of the local culture, the politization of Diyanet's institutional culture, and the secularization of young immigrant identity. While discussing these factors, I evaluated their role in the formation of the public image of imams. The results indicate that the image of the imam in Dutch-Turkish Muslim communities is not uniform. On the one hand, there are the educated interviewees and spiritually oriented respondents, who generally criticize the ignorance of most imams and the irrelevance of their sermons to young Muslims in Europe. On the other hand, there are the less educated respondents and the respondents who strongly experience popular religiosity, who do not question the authority of imams. The image of the imam in the minds of the majority of Dutch-Turkish Muslims is positive and retains its authority.
\end{abstract}

Keywords: image of imams; secularization; plurality; spiritual religiosity; popular religiosity; radicalization

\section{Introduction}

The variety of Muslims living in Europe in terms of regional origin and ethno-national identity plays an important role in the make-up of Islamic religiosity in Europe, because the Islamic orientation in the countries of origin is still influential on Muslim immigrants, especially when it comes to Turks [1,2]. This justifies examining the diversity of Islam within a single group, such as Pakistani, Moroccan or Turkish Muslims. The focus on a single religion, however, brings the risk of constructing Muslims as a coherent group while ignoring the inner-Islamic differences and the characteristics that some Muslims share with other individuals and groups [1]. There exist various sources of religious diversity within a single ethno-national Muslim community, and Turkish society today experiences various types of religiosity as well [3-5]. Therefore, the inner-Islamic differences to which I draw attention in my PhD study are of great importance in understanding and explaining the behaviors and everyday experiences of the Muslim communities in the Netherlands [1]. Taking these inner-Islamic 
differences into account, this study is concerned with investigating how the image of imams is shaped in the minds of Dutch-Turkish Muslims in relation to spiritual (elite) religiosity and popular religiosity.

Public debates in the Netherlands assume there is an inherent tension between the traditional task of the imam and his tasks in the secularized Dutch society. According to some scholars, mosque imams in the 1980s and 1990s had a much larger influence in the diaspora than in their home countries, because of the multiple functions that the mosque fulfilled in the diaspora [6,7]. Imams were in close contact with the public when performing their duties, which positively affected the public image of the imam. Today, however, second- and third-generation migrants tend to understand the language of their country of residence better than the mother tongue of their parents or grandparents, which has implications for the success of these imams in the Netherlands [6].

Studies of the effect of age and generation on religiosity report that intense religious changes are taking place among second-generation migrants [8-15]. But the direction of this change is interpreted differently by scholars. A majority of scholars indicate that second-generation migrants from North African or Turkish migrant families consider themselves more 'Muslim' when compared to their elders. The second generation is more religious, in the sense that it is more strict in its observance of the rules of Islam and its search for an authentic or 'pure' Islam, i.e., an Islam based on its normative sources that is more concerned with traditional sources of authority [1,2,5-10]. However, a different analysis shows that there is an ongoing pattern of secularization among Muslims in Europe: the longer Muslim migrants stay in Europe, the higher their level of education, and the more they participate in the labor market, the less concerned they become about traditional and popular sources of religious leadership and authority [1,16-19].

This paper examines theoretical and practical questions about the evolving role of the Turkish imam in the Netherlands. I will evaluate possible factors that shed light on different findings related to the results of my PhD study.

\section{Methodology}

This article was written based on the results of my five-year (2013-2018) research project on Dutch-Turkish Muslims [1], in which I used both qualitative and quantitative research techniques.

The main objective of my PhD study was to contribute to the available knowledge about the characteristics of spiritual (elite) religiosity and popular religiosity as practiced by Dutch-Turkish Muslims who live in the Dutch plural society. The main objective of this article, however, is to contribute to the available knowledge about the most important socio-psychological factors that affect the formation of the image of the imam within the same community. The following research questions were asked in this article: 'how is the image of the imam shaped in the minds of Dutch-Turkish Muslims in relation to spiritual (elite) religiosity and popular religiosity' and 'what are the most important socio-psychological factors that affect the formation of this image'.

In order to answer this question, I used some of the qualitative and quantitative data from my $\mathrm{PhD}$ research that is directly related to the main theme of this paper. Quantitative data were collected in two ways: by means of a paper survey and through a modern web-based approach. The paper surveys were distributed in various Turkish Islamic centers, mosques, Islamic schools, Islamic organizations and secular societies such as coffeehouses, sport clubs, and a number of other cultural organizations. The larger part of the data $(60 \%)$ was collected by using a modern web-based approach, Google Docs. This Google Docs-designed survey was embedded in an email and sent to addresses that were randomly collected through social network sites such as Facebook, LinkedIn and Twitter. Some websites that are often visited by Turkish citizens embedded the survey link in their forum page at our request [20]. We also sent thousands of messages to the collected Facebook addresses, on a random basis. 1165 Turkish Muslim participants took part in the survey. There were 649 male and 516 female participants, varying in age between 18-68 years. The data from the completed questionnaires were entered and analyzed in the SPSS 23.0 program (Statistical Package for the Social Sciences). 
Qualitative data were collected in two ways: by means of participant observation and through informal interviews. Participant observation involves collecting social data in their natural social setting, through which researchers have access to the meaning of events and social interactions as understood by the group or organization under study. In the qualitative part of my PhD study, I usually took on the role of a 'complete participant' (in virtue of my background) and of a 'participant-as-observer', in order to gain access to a larger group of participants with their social connections. During my research project on Dutch-Turkish Muslims in the Netherlands, I set myself the goal of visiting Dutch-Turkish mosques that displayed different ideological patterns. I attended conferences, Friday prayers, and sometimes joined a kermis [21]. During the research phase, I took on several volunteer tasks in Turkish organizations and institutions. These volunteer tasks made it possible for me to collect data while I was working within the communities themselves. Briefly summarized, as a volunteer I was expected to teach the basic values of Turkish culture and the concepts of Islamic faith. I used informal conversational interviews to gather general information about cultural and religious issues and participants' expectations of these institutions, interviewing both educators and imams. These insider positions provided me with excellent opportunities for in-depth interaction with various sections of the Turkish community in the Netherlands, in order to understand the meaning that Dutch-Turkish citizens ascribe to culture and religion, and the processes that are at work in the formation of the imam image of these citizens in the context of a multicultural society. In addition, these informal conversational interviews were very useful for setting up the theoretical framework of my PhD study, and for developing hypotheses and survey items during the development of the research questionnaire. During my field research, I conducted 15 informal interviews with imams $(9 / 15)$ and administrative staff (6/15) in five mosques in The Hague (2), Rotterdam, Utrecht and Leiden, and 66 informal interviews with parents and their children through paper-based survey (these interviewees attended Diyanet mosques in The Hague and Leiden, and a private Qur'ān course in The Hague).

\section{Results}

This section contains only the findings of my PhD study that closely relate to the subject of this article. Of the 1165 respondents, $272(23.3 \%)$ were excluded, because due to their low religious commitment-they were unable to contribute to my PhD research on the forms of-and motivations behind — different aspects of high religiosity. My analysis was therefore focused on the remaining 893 respondents $(76.7 \%$ of the initial sample (1165)) who display strong religious affiliation. Of the 893 $(76.7 \%)$ respondents with a strong religious affiliation, $203(22.7 \%)$ turned out to consistently experience spiritual (elite) religiosity, while 545 (61\%) consistently experienced popular religiosity. This result shows that Turkish Muslims living in the Netherlands predominantly experienced popular religiosity.

Factor analyses and correlation analyses performed on my PhD study's spiritual and popular religiosity scale revealed that participants who experienced spiritual religiosity tended to stress doubt and dynamism. They tended to stress the intrinsic value of rituals (i.e., focus on quality). In addition, they underlined the importance of doubt about the validity of their current religious knowledge, and the dynamism of religious learning. Participants who experienced popular religiosity tended to stress the sureness and the stability of their current beliefs. They stressed the extrinsic value of rituals (i.e., focus on quantity) and expressed material expectations. In addition, they tended to be sure of their current religious knowledge, and placed intellectual stability at the center. I also found a negative correlation between spiritual religiosity and popular religiosity $(r=-0.72)$. This result suggests that increase in one aspect of religiosity is correlated with decreases in other aspects of religiosity.

In my PhD study, the respondents were asked how much religious education (RE) that is provided in mosques influenced their religious development. I found that spiritual religiosity was not significantly correlated with RE provided in mosques, while popular religiosity was positively correlated with mosques $(r=0.24)$. 
Six variables in the PhD study were chosen to measure the intellectual aspect of religiosity. One of the variables (v70) particularly addressed the confidence of interviewees in the intellectual capacities of their imams. This variable was formulated as follows: 'when I find answers to my religious questions through imams, I do not doubt their correctness'. The respondents were asked to answer on a five-point Likert scale ( 5 referred to 'fully agree' and 1 to 'fully disagree'). There was a significant difference in the scores for popular religiosity $(M=3.8, S D=0.96)$ and spiritual religiosity $(M=2.0$, $\mathrm{SD}=0.97)$ conditions; $t(746)=22.28, p=0.000$. These results suggest that the type of religiosity that Dutch-Turkish Muslims experience does have an effect on their image of the intellectual capacities of imams. Specifically, our results suggest that when people experience spiritual religiosity, they trust imams less compared to those who experience popular religiosity.

A Pearson correlation coefficient was computed to assess the relationship between the intellectual image of imams held by the interviewees, and three other variables. There turned out to be a positive correlation between popular religiosity and the intellectual image of imams, $r=0.365, n=545, p=0.000$; and a negative correlation between spiritual religiosity and the intellectual image of imams, $r=-0.211$, $n=203, p=0.003$. In addition, there was a negative correlation between educational status and the intellectual image of imams, $r=-0.173, n=893, p=0.000$. Overall, increase in popular religiosity was correlated with a positive image of the intellectual capacities of imams. Furthermore, there was a strong negative correlation between the intellectual image of the imam and two other variables, i.e., increase in spiritual religiosity and educational status, both of which were correlated with decreases in a positive image of the intellectual capacities of imams.

In regard to the field work of my PhD study, it is worthwhile to inform the reader about the qualitative data I collected, and the characteristics I observed, of imams in relation to their language skills and knowledge of Dutch culture. The various Turkish-Islamic communities in the Netherlands—who all have their own mosques and own imams—specifically selected imams with an identical socio-religious background in Turkey. The majority of these imams were not competent in many regards even though they received higher education: they could recite the Qur'ān in phonetic Arabic, but did not understand the language; they knew little more about Islamic law than the basic elements, which they had not been taught to interpret.

Imams were expected to provide RE for pupils during weekend classes. One of my field observations in Qur'ân weekend schools took place in one of the four Diyanet mosques in The Hague. The ages of the pupils who took part in these Qur'ān classes ranged from 13 to 18. There was no school class system and children of different ages sat together in a single room. The instruction during the lessons consisted first and foremost in the memorization of the Arabic alphabet using elifbâ cüzü, followed by reading Qur'anic sections of Amme cüzü, i.e., from Surah 78 to the end of the Qur'ān. These were the popular Diyanet teaching tools. The main goal of these lessons was to teach the pupils to read the Qur'ān aloud in fluent Arabic, and to instruct them in the memorization of short sections of the Qur'ân, without pondering on the meaning of the passages (ayah) or sections (surah). In other words, the focus was on exoteric knowledge of Islam. The majority of the imams (5 out of 9) did not attend weekend RE classes themselves. When I interviewed them, the majority of them openly spoke of their lack of language skills and knowledge of the local culture, and asked me whether I (as a Muslim RE teacher) could help them with their weekend classes in view of their difficulties to communicate with the pupils.

In addition, the books these imams and educators read during weekend classes were books on ablution (i.e., books that instruct students on how to perform the requirements for prayer such as the ghusl (the full-body ritual purification) and the wudu (washing parts of the body)). This literature was therefore mainly focused on the legal (figh) aspects of praying. Many of these books are published by the Presidency of Religious Affairs (the Turkish branch of Diyanet) with a view to children that grow up in Turkey—books that are reproduced and distributed by the Dutch Islamic Foundation (ISN) without any additions or adjustments for the new context. It was almost impossible to find a Dutch 
source that was more relevant to the pupils in class, and that would point them towards the spirit of Islam.

Diyanet's statements about the recruitment of imams are largely in line with these characteristics. Diyanet does not impose any conditions regarding familiarity with the national language and culture of the host country in which imams will be appointed. According to Diyanet's recruitment exam, imams need to be knowledgeable about tajweed (which refers to the rules for pronunciation during the recitation of the Qur'ān), exegetics, figh (Islamic law), hadith (records of Muhammad's words and actions), and Islamic history [22].

\section{Discussion}

My PhD study suggests a number of demographic and socio-economic factors to explain the formation of the image of the imam, and the changing authority of imams among Turkish Muslims who live in the Dutch plural society. I will present a few of these as figuring in the framework of information I obtained in the field during my research project. These factors are: (1) a lack of language skills and knowledge of the local culture; (2) the politisation of Diyanet's (Turkish Presidency of Religious Affairs) institutional culture; and (3) the secularisation of young immigrant identity. While discussing these factors, I evaluate their role in the formation of the image of imams.

\subsection{Lack of Language Skills and Knowledge of the Local Culture}

An initial relevant category of research for the current and future status of imams in Europe-one that is connected to the issue how this status affects their image among Dutch-Turkish Muslims - concerns imams' lack of language skills and knowledge of the Dutch culture, as I outlined above. During the interviews, the majority of imams spoke openly of their lack of language skills and knowledge of the local culture, and the main problems caused by this knowledge deficit. As I addressed above, Turkish-Islamic communities do not impose any conditions regarding familiarity with the language and culture of the host country. Some scholars suggest that this problem stems from the desire of Turkish institutions to maintain their ideological structures in the host country [23,24]. It should be noted that when Islamic educational groups started to organize themselves in the Netherlands in the 1970s, this happened under the same impulse as in Turkey, where the Qur'ān schools undertook pioneering work in formal and informal RE for the Muslim community.

As Yükleyen reports, the relations between the various Turkish Islamic communities—such as Milli Görüş, the Nur Movement, Süleymancı, Diyanet, and others-are largely based on competition. This has led to confrontations when organizational interests-such as various ideologies and different interpretations of Islam-clash [25]. Differences in imam training and the failure to establish a representative body for Muslims are symptoms of this ongoing clash of interests.

The questions that arise in Dutch public debates revolve around two central issues: the transmission of Islam to young people living in European secular societies and, on a more abstract level, the criteria that 'appropriate' leaders of European Muslim communities must meet. Can they act as intermediaries between European and Islamic societies? Do they have sufficient knowledge of the host country to counsel young people? To what extent do the countries of origin exert political and ideological influence on Muslims in the host countries through these key figures? How can these imams function in the host society if they do not speak Dutch? How do they interpret the norms and values of their host societies? Should they not receive their training in the host country rather than in their country of origin $[26,27]$ ? These pressing questions and the changing political climate stimulate the development of an educational program for imam training in the Netherlands [28], which has gone through a very complex process of discussion and negotiation over the past three decades [23]. The issue remains highly relevant today [29].

The lack of Dutch language skills and knowledge of Dutch culture among imams was perceived as a major obstacle to the integration of Muslims. With regard to second-generation radicalization, Tillie [30], Kepel [31] and Roy [32] indicate that many young people reject a large part of their parents' 
(and their imams') understanding of Islam as irrelevant local culture, and that their search for a 'pure' Islam without culture almost inevitably draws them towards Salafism (cf. [33]).

In response, the Dutch government set up pilot programs in Islamic theology in 2005 [34]. In 2007, the government funded imam training initiatives, arguing that training for imams in the Netherlands can make an important contribution to the integration of young migrants in particular, and help them to defend themselves against radicalization [26]. It was also suggested that imams trained in the Netherlands would be better acquainted with the Dutch situation [35]. They could act as a bridge between the Muslim communities and the rest of Dutch society and thus contribute to the integration of Muslim migrants [36]. In light of this, the Dutch government set itself the goal of developing a socio-cultural policy that included religion and 'life principles' [37].

Over the past decades, the Dutch Diyanet Foundation (Islamitische Stichting Nederland, ISN, this is the Dutch branch of Diyanet) succeeded in becoming the largest mosque organisation in the Netherlands, controlling 146 of the 220 Dutch-Turkish mosques [38,39]. However, the official representatives of Turkish Islam in Europe-Diyanet among them-refrained from participating as partners in the educational project set up by the Dutch government. Diyanet interviewees of my study report that this unwillingness is due to reservations about the adequacy of the Dutch state curriculum and the competence of the teachers who would give the lessons [23]. The training of imams in Europe and the recruitment of candidates among Muslims living in Europe have not been Diyanet's priorities in recent years. Instead, Diyanet draws from a vast pool of candidates trained in Turkish high schools for imams (imam hatip lisesi) and from preachers and students at their theological faculties. However, the increasing criticism of this policy by European politicians and European Muslims prompted Diyanet to take up this issue and to enter into negotiations on setting up imam training facilities in Europe [39]. Diyanet eventually chose to develop its own project, whereby Muslim students who graduated from the Imam Hatip School in the Netherlands [40] would move to Turkey to study at Turkish theology faculties under Turkish scholars. In this way, young Muslims who had been predominantly immersed in the Dutch language and culture, could learn the Islamic sciences directly from Muslim scholars and become the new generation of imams in Europe. Under this policy, the Imam Hatip School—supported by Diyanet-began to work in 2013 under the umbrella of Ibn Ghaldoun, an Islamic school for VMBO, HAVO and VWO [41] students in Rotterdam [42].

The project of the Dutch government ended due to high costs and low participation of Muslim students [29]. In addition, the Dutch Ministry of Education terminated Diyanet's project [43] because of a scandal (implying stolen final exams) that broke out at the time [44], resulting in the closure of the Ibn Ghaldoun school [45]. Because of these developments, the lack of language skills and knowledge of the local culture seems to remain a complex problem for imams in the Netherlands.

\subsection{The Politisation of Diyanet's Institutional Culture}

A second relevant avenue of research for the current and future status of imams in Europe concerns the status of transnational Turkish Muslim organizations. Here, I will focus on the role played by Diyanet because of this organization's immense influence in Europe. However, it is worth addressing first a report that was published in 2012 by the Dutch Social Cultural Planning Bureau (SCP, a scientific institute that conducts social scientific research and reports to the Dutch government). The SCP observed that Dutch-Turkish citizens score low on 'integration' compared to other groups; they have less contact with the Dutch majority society. According to the SCP, this low integration score could be linked to a number of factors. One of the possible factors is the strong attachment to religious organizations within the Turkish community [46]. The data coming from my field study confirms the findings of SCP. My findings show that Dutch-Turkish Muslims predominantly experience popular religiosity, and that participants who experience popular religiosity display more conservative in-group attitudes than participants who experience spiritual religiosity [1].

The real power in the mosque is not in the hands of the imam but of the organizing committee, the executive board of the association. The imam is supposed to have more specialized knowledge 
than the board members, but it is they who call the shots-as becomes clear in the event of a conflict, when it is the imam who has to go [6] (p. 8). The religious guidance provided by Diyanet is a balancing act between people's religious traditions, the demands/challenges of living in a plural and secularized Western society, and the restrictions imposed by the Turkish state [41]. This balance sometimes swings in favor of the people and sometimes in favor of the Turkish state $[47,48]$. The latter seems to be more the case today because of the current political situation in Turkey [49].

Turkey is a laik [50] country. This suggests that the state and the country's religious institutions do not hinder each other's activities. However, investigations of religious groups and institutions in Turkish civil society suggest that religion does not function as an autonomous sphere outside the state's control. To give an example: the state has not been neutral in its relationship with minority religions, as shown by the case of the Alevis [51]. This is why Turkish secularism is often labelled as incomplete-i.e., as an explicit form of secularism where it is the state that controls religion [52] (p. 224) [53] (p. 15), or as a deviation from the original model of French laïcité. In the Turkish case, laïcité rather means 'the subordination of Islam to state objectives, and active management of religious institutions and affairs by the state' [54] (p. 234). A decisive step in controlling Islam was the foundation of the Presidency of Religious Affairs (Diyanet İşleri Reisliği [now Başkanlığı]) in 1924 [55]. The Presidency coordinates religious learning and training inside Turkey and in 'the diaspora communities', prepares the Friday sermons, and enforces the state-sanctioned conduct of all its employees.

This being said, it must be acknowledged that the importance of religious topics in public discourse has changed time and again since the foundation of the Turkish Republic, and that state pressure on or state support for religion—or religious communities and religious currents-has gone through different phases. It is an unquestionable fact that the former balance between, and co-existence of, (1) scholastic ('orthodox') Islam; (2) popular Islamic beliefs and practices; and (3) mystical and spiritual Islam (Sufism) has been destroyed by the implementation of a model of Sunni Islam that envisions state-controlled institutions as the only legal framework for religious activities, while simultaneously banning and demonizing independent activities or communities, especially those inclined towards mysticism [56] (p. 3).

In recent years, Diyanet has increased its influence in Europe through its mosques, and has begun to play a more active and effective role in assisting state politics and developing activities that would make it more deeply embedded in everyday life [40] (p. 209). Gürlesin explores how Diyanet's religious discourse influences Turkish imams who work in the Netherlands. He asks, 'how is the content of the sermons affected by changes in Diyanet's policy?' [57] As pointed out above, the real power in the mosque is not in the hands of the imam but of the organizing committee. The Friday sermons are not written by the mosque imam, but published a few days in advance on the Diyanet site of the committee. Religious officials download this sermon from the internet and read it during the Friday prayer. If they deviate from this procedure, they face the risk of dismissal [58]. One manifestation of Diyanet's nationalized voice occurred during Operation Olive Branch [59]. The Turkish Presidency of Religious Affairs instructed more than 90.000 mosques in Turkey to recite chapter 48 of the Qur'ân-a chapter on conquest (Al-Fath) — and invited mosque communities to pray for the troops during the Turkish military operation in Syria. The accompanying Friday sermon, calling for jihad and martyrdom, was preached in at least one Turkish mosque in the Netherlands [60]. With this dictated sermon, the Turkish government wanted to give religious support to its controversial attack on Kurds in Syrian Afrin. In the Netherlands this sermon was read in the mosque in Hoorn:

Our soldiers show the whole world that we unquestioningly sacrifice everything to protect our faith, flag and country. ( ... ) Every son of our country who, in the power of his life, drinks the sweet nectar of martyrdom, shouts this to us. (... ) He who dies in the way of Allah, never call him dead, but call him alive. ( ... )

Dramatic changes after the failed coup attempt on 15 July 2016-directed against Turkish state institutions-seem to be profoundly affecting Diyanet's narrative both in Turkey and in Europe. Just one decade ago, concepts like cohesion and integration and positive interaction between adherents 
of different religions and/or spiritual or humanistic beliefs were being used to describe the relationship between Turkey and Europe. But in 2016, circumstances changed completely and so-called 'Turkishness', anti-western resentment and a strong attachment to Turkey's sovereignty once again became strong motivations. These changes give way to the voice of Turkish civil religion, which refers to the sacralization of the state through Islamic symbols. The way basic Islamic concepts are being interpreted in Turkey nowadays is strongly influenced by these changing circumstances. In times when peace and reconciliation are pursued, the concept of jihad is interpreted as the struggle against the animalistic forces within oneself, while in politically tense times-when conflict is pursued-the same concept is interpreted as the struggle against 'infidels' ( $k u f r)$, and being linked to concepts of sacrifice and martyrdom, as becomes clearly visible in the above example [57].

Consequently, in the short term it is pretty unlikely that Diyanet, or the imams appointed by Diyanet, will stimulate inclusive and holistic principles of religion that create space for spiritual insights (the search for meaning, inner emotional satisfaction). Currently, social and political activism prevails over spiritual considerations in Turkey and in Europe; in such cases, religion is no longer just religious. The meanings that are being produced are not just focused on the spiritual life or the life within the religious community anymore, but also include political, nationalistic and ethnic interests that serve the in-group, as tools for the in-group to reassure itself of its identity and to separate itself from out-groups [61]. From the perspective of a cultural psychology framework it is crucial to recognize that without differences and ambiguities, meaning-making processes are not possible. In some cases, symbolic boundaries transform (a) from differences into inequalities; and (b) from inequalities into intolerance [62,63]. In extreme cases, when the symbolic boundaries become more rigid, the 'others' ('they', 'those people') become socially perceived as (c) enemies that should be eliminated [57]. In this context, the voice of Yūnus Emre who eagerly expressed the unity of differences is being consistently ignored, while the voice of Molla Kasım, who emphasized the destruction of differences, is attributed greater value [64]. In such conditions, the struggle for power overshadows the quest for meaning.

This ethnoreligious voice of Diyanet also has an effect on its authority in general, and on the image of imams in particular. The politization of the language used by Diyanet might have different effects on Muslims in the short run. Under the influence of this voice, some young Muslims who strongly experience popular religiosity could place their trust in imams without questioning the correctness of their imams' interpretations and fatwas (legal opinions), prompting them to exhibit radical tendencies [65]. In an atmosphere where conflicts arise and existential security is threatened, popular religiosity can acquire a fundamentalist character, of which one element is a strong sense of belonging to a group. Another group of minorities, particularly those who experience spiritual religiosity, might widely lose their trust in imams and the institutionalized forms of religiosity. This creates a space for a new, de-institutionalized form of religiosity, and young Muslims might gradually turn to alternative religious sources separate from the mainstream, which might be new spiritual or Salafi religious movements.

\subsection{The Secularisation of Young Immigrant Identity}

In the above two sections, I discussed the status of imams in the Netherlands by focusing on the imams themselves and the institution they are dependent on. In this section, I will analyze the status of imams by focusing on the status of the young Muslim generation living in Europe.

Islam in the EU countries displays a range of differences which are linked to the countries of origin. The findings of my $\mathrm{PhD}$ research project, which largely revolve around a Dutch-Turkish sample, are to a certain extent in line with the findings referred to above, which report the secularization of the second generation (cf. [58]). However, in my PhD study, the phenomenon of secularization does not signify moving away from religion, but moving away from traditional and popular aspects of religious authority. Secularization among Dutch-Turkish Muslims largely relates to deinstitutionalization, and trends in personal piety and the new forms of 'spiritual' religiosity. Religious individualization is one of the important components of the secularization process. According to the individualization 
thesis, young people go in search of their own meaning given to, and interpretation of, their faith-they do not unquestioningly follow what the imam or their parents instruct them. My own PhD study also shows that $203(22.7 \%)$ respondents who experience spiritual religiosity are not influenced by RE provided by mosques, and prefer to develop their own religiosity and find their own answers, independent from the mosque [1] (p. 185). In such a context the following question arises: what is the image of imams among Dutch-Turkish Muslims who experience spiritual and popular religiosity?

It would be premature to look at these findings and say that the influence of imams will gradually disappear. If we consider other factors, it can be argued that this tendency towards secularization among young people might decrease with increased age and that popular religiosity could become stronger again. Specifically, my findings suggest that there is a positive correlation between age and religiosity [1] (p. 180). Sociologists have specified how religiosity changes depending on age or life-cycle events, such as leaving the parental home or marriage. These are referred to as 'age effects' on religiosity. This approach assumes that the effects of aging on religiosity are constant over time [66]. For example, young adults may currently show little institutional religious involvement, but when they are 40 and married, their involvement in a religious community will increase, and when they are 60 and face death, that involvement will increase even further. Present-day Muslim youth who do not highly experience popular religiosity, could exhibit increased popular religiosity as they get older. Young people are a less socialized population group and are therefore less likely to assume traditional roles, which may reduce their interest in popular aspects of religiosity. Older people, on the other hand, invest more in traditional role patterns, attitudes and beliefs, and are less motivated to re-examine them. These beliefs might make them more receptive to traditional and popular religiosity $[67,68]$.

One of the challenges, therefore, lies in the task to find the appropriate measurement tools that will allow us to comprehend the different characteristics of religiosity among Dutch-Turkish Muslims. What distinguishes spiritual religiosity and popular religiosity in my PhD study, is not a commitment to certain beliefs and practices, but different motivations and cognitive styles. One of the possible reasons behind the different findings about religiosity could stem from the use of monolithic and one-dimensional approaches. Most of the studies which I outlined in the introduction do not measure the difference between various religious orientations, such as spiritual and popular religiosity, but between high and low religiosity. These measurements no longer seem to be sufficient to understand complex characteristics of the religiosity of individuals. There is a growing need to assess the variety of religious orientations.

Therefore, the diminishing authority of imams among young Dutch-Turkish Muslims cannot be understood by looking at just one factor. Focusing solely on the secularisation of young immigrant identity, and the tendency of young people to show little institutional religious involvement, can be an obstacle to evaluating the actual situation of imams in the Netherlands.

\subsection{The Future Image of the Imam}

After discussing the above-mentioned issues, I will now further evaluate the role of these factors in the shaping of the image of the imam. It appears that the image of the imam in the Dutch-Turkish Muslim communities is not uniform.

On the one hand, there are the educated interviewees and spiritually oriented respondents, who generally criticize the ignorance of most imams and the irrelevance of their khutbas (sermons) to young Muslims in Europe. These are Muslims who have, to a certain extent, become dissatisfied with imams whose experiences have no connection with their own-Dutch-lives. In my PhD study, I found that spiritual religiosity is not significantly correlated with RE provided by the mosques, and that individuals who experience spiritual religiosity have less confidence in imams compared to those who experience popular religiosity [1] (pp. 214-226). The demand for better imam education often comes from these circles. These Muslims have begun to nurture their own Islamic self-understanding and feel no need for religious guidance or authority. Above I mentioned that it has been observed that some of the young Muslims prefer to develop their own religiosity and find their own answers, independent of 
mosques or religious specialists (cf. [68-72]). All these developments threaten the position of the imam as a religious authority. According to some interviewees, an imam with insufficient knowledge of Dutch is seriously handicapped in his communication with Muslims of the second and third generation [37].

During the field work, I observed that imams working in the Netherlands do not sufficiently address the crucial problems that young people face nowadays in a secular and multicultural society. The only source of information available to these imams for finding solutions to these problems are traditional jurisprudence (figh) books. Religious solutions (fatwas) produced in the socio-psychological contexts of Turkey seem to fail when they are applied in Western societies. One interviewee, Yunus (44), stated that:

When I have a question on my mind, I prefer to just look for an answer on Google rather than talking to imams. My friends don't want to ask their imams any more questions either, because they already know that they won't have the right answer. Unfortunately, the imams come from Turkey and you can't apply their answers here.

Imams who are aware of this problem try to work on solutions. It is not unheard of that imams are afraid to work as instructors during the informal religion classes held in the mosques during the weekend. The majority of the imams (five out of nine) in my study, as pointed out above, did not attend the weekend RE classes themselves. Officials have been developing an attitude of indifference and 'laziness' towards their work, and have lost the ability to be socially responsive. Something similar took place in the context of state-supported religious monopolies in pre-modern and early modern Europe [73]. A considerable number of Turkish Muslim migrants, consequently, are faced with the challenge of reconciling their religious identity with the Dutch culture in which they grew up [74].

This being said, I found that the majority of Dutch-Turkish youth did not question the adequacy of their imams. Consistent with the qualitative results, the quantitative findings revealed that those who highly experience popular religiosity $(61 \%)$ were much less likely to question the answers given by the imams, compared to those who highly experience spiritual religiosity (22.7\%). The image of the imam in the minds of the majority of Dutch-Turkish Muslims is positive and retains its authority. According to this group of interviewees, the politization of Friday khutbas (sermons) is not problematic. According to some, such sermons are even essential for the upbringing of the youngest generation. One interviewee, Ahmet (47), stated that:

I think it's important that religious officials emphasize both religious and national values in their sermons, and that they educate and raise young people as individuals who are strongly attached to their homeland and their nation.

To give another example: one of the young imams working in the Netherlands, who was trained in Turkey and taught very rigid rules about halal and harām—right and wrong Muslim behavior-did not make the slightest effort to adapt his teaching to the Dutch context. He still became popular in the mosque community and was successful in changing the behavior of young people. This imam was also popular with the mosque committee, and after his inspiring success with young people he was appointed to one of the central Diyanet mosques as a leading imam.

\section{Conclusions}

Many religious organizations 'import' imams and ulame (scholars in religious sciences) from Turkey, Egypt, Pakistan and Bangladesh to provide guidance in matters of faith and practice, and to prevent the different generations of Muslim immigrants from ending up in an identity crisis. Based on my PhD research, some young and spiritually oriented Muslims find the RE provided by imams particularly dogmatic and narrow-minded, in terms of the view of Islam held by these officials. According to this group, questions and challenges in the mosque are not tolerated, and a part of the younger generation grows increasingly frustrated at being told, when they question certain aspects of Islam, that 'that is just the way it is'. However, it is too early to conclude that the entire generation 
of European Muslim youth, and those who highly experience spiritual religiosity, have turned away from the traditional and popular sources of religious leadership and authority. We must bear in mind that in many European countries, particularly in the Netherlands, we are witnessing the revival of traditional and popular religious forms in addition to the appearance of new religious movements and new religious spiritualities, parallel to the continuation of the secularization process.

Some theories related to the age factor-listed above-must be taken into consideration to understand the future status of the imam among Dutch-Turkish Muslims. Some other factors were briefly presented in the previous sections. These factors are (1) a lack of language skills and knowledge of the local culture; (2) the politization of Diyanet's (Turkish Presidency of Religious Affairs) institutional culture; and (3) the secularization of young immigrant identity. Moreover, based on my field research, there are various significant socio-psychological factors that affect the religious tendencies of Muslims. Examples are: educational status, household income, social and cultural capital, the experience of immigration, structural and contextual factors such as the current economic and political crisis, government policies, and experiences with discrimination because of religion. Without seriously considering these factors, it is difficult to understand what kind of religiosity Muslims will experience in the nearby future, and what sort of image of imams they will have and develop.

However, it seems that a considerable number of younger Muslims-who are highly educated and spiritually oriented-are looking for a more sophisticated form of Islam. The three factors listed above play an important role in this new search for meaning. It seems unlikely that the imams appointed by Diyanet, who have a temporary mandate and lack language and cultural skills, will be able to meet the spiritual and intellectual needs of Dutch Muslims. The emphasis that imams place on Turkish civil religion in the Dutch context does not provide any resources to tackle the issues and problems that these young Muslims face in their daily lives. What is needed, rather, is a renewal and a reinterpretation of Islam so that it speaks directly to the circumstances of being a Muslim in 21st century Europe. Research on spiritual education can help imams and educators to reconsider their educational orientations and goals, and to apply new approaches that can meet the challenges of today's society. Research on religious and spiritual education can offer valuable practice-oriented insights that improve the development of educational practice. Thus far, there is a lack of such research-based data. In terms of future theoretical development in formal and informal RE methods, I recommend the construction of conceptual bridges between traditional religiosity and spiritual religiosity using the Dialogical Self Theory [75]. If Turkish imams and the Turkish and Dutch authorities do not supply such conceptual bridges and intellectual foundations to Dutch-Turkish Muslims, I believe this would create fertile ground for the existence of pro-violence groups.

Funding: This research received no external funding.

Conflicts of Interest: The author declares no conflict of interest.

\section{References and Notes}

1. Gürlesin, Ö.F. Elite and popular religiosity among Dutch-Turkish Muslims in The Netherlands. Ph.D. Thesis, Leiden University, Leiden, The Netherlands, 28 November 2018.

2. Huijnk, W. De Religieuze Beleving van Moslims in The Netherlands; Sociaal en Cultureel Planbureau: Den Haag, The Netherlands, 2018.

3. Akşit, B.; Şentürk, R.; Küçükural, Ö.; Cengiz, K. Türkiye'de Dindarlk: Sosyal Gerilimler Ekseninde Inanç ve Yaşam Biçimleri [Religiosity in Turkey: Faith and Life Styles in the Axis of Social Tensions]; İletişim Yayınları: İstanbul, Turkey, 2012.

4. Arslan, M. Türk Popüler Dindarlığı [Turkish Popular Religiousity]; Dem Yayınları: Istanbul, Turkey, 2004.

5. Kirman, M.A. Din ve Sekülerleşme: Üniversite Gençlili Üzerine Sosyolojik bir Araştırma [Religion and Secularization: An Sociological Inquiry on University Students]; Karahan Kitabevi: Aladağ/Adana, Turkey, 2005.

6. Bruinessen, M. Van Producing Islamic knowledge in Western Europe: Discipline, authority, and personal quest. In Producing Islamic Knowledge/Transmissions and Dissemination in Western Europe; Van Bruinessen, M., Allievi, S., Eds.; Routledge: Abingdon, UK, 2011; pp. 1-28. 
7. Poston, L. Islamic Dawah in the West Muslim Missionary Activity and the Dynamics of Conversion to Islam; Oxford University Press: New York, NY, USA, 1992.

8. Roeland, J.; Aupers, S.; Houtman, D.; De Koning, M.; Noomen, I. The Quest for Religious Purity in New Age, Evangelicalism and Islam Religious renditions of Dutch youth and the Luckmann legacy. In Annual Review of the Sociology of Religion; Brill: Leiden, The Netherlands; Boston, MA, USA, 2010; pp. 289-306.

9. Bartels, E. Dutch Islam: Young people, learning and integration. Curr. Sociol. 2000, 48, 59-73. [CrossRef]

10. Buijs, F.J.; Demant, F.; Hamdy, A. Strijders van Eigen Bodem: Radicale en Democratische Moslims in The Netherlands; Amsterdam University Press: Amsterdam, The Netherlands, 2006.

11. Buitelaar, M. Islam en Het Dagelijks Leven. Religie en Cultuur onder Marokkanen; Atlas: Amsterdam, The Netherlands, 2006.

12. Buijs, F.J. Muslims in The Netherlands: Social and Political Developments after 9/11. J. Ethn. Migr. Stud. 2009, 35, 421-438. [CrossRef]

13. Korf, D.J.; Bovenkerk, F. Dubbel de Klos. Slachtofferschap van Criminaliteit onder Etnische Minderheden; Boom Juridische Uitgeverij: The Hague, The Netherlands, 2007.

14. Azak, U. Islam and Turkish Iimmigrants in The Netherlands. Turk. Stud. Int. Period. Lang. Lit. Hist. Turk. Turk. 2008, 3, 136-162.

15. Berger, M.S. The Netherlands. In The Oxford Handbook of European Islam; Cesari, J., Ed.; Oxford University Press: Oxford, UK, 2015; pp. 158-221.

16. Şen, F. Euro-Islam: Some emprical evidences. In Islam and Muslims in Germany; Al-Hamarneh, A., Thielmann, J., Eds.; Brill: Leiden, The Netherlands; Boston, MA, USA, 2008.

17. Phalet, K.; Haker, F. Moslim in The Netherlands. Diversiteit en Verandering in Religieuze Betrokkenheid: Turken en Marokkanen in The Netherlands 1998-2002; Sociaal en Cultureel Planbureau: Den Haag, The Netherlands, 2004.

18. Phalet, K.; van Praag, C. Moslim in The Netherlands. Een Onderzoek naar de Religieuze Betrokkenheid van Turken en Marokkanen; Sociaal en Cultureel Planbureau: Den Haag, The Netherlands, 2004.

19. Lans, J.M.; Rooijackers, M. Types of religious belief and unbelief among second generation Turkish migrants. In Islam in Dutch Society: Current Developments and Future Prospects; Kok Pharos: Kampen, The Netherlands, 1992; pp. 56-66.

20. Een sociologisch Onderzoek naar Religiositeit. Available online: http://forums.hababam.nl/showthread.php? $\mathrm{t}=156462 \& \mathrm{~s}=76324 \mathrm{f76fe0cf2ad97e3ce0afd84a0fd}$ (accessed on 12 June 2018).

21. Kermis is a Dutch term derived from 'kerk' (church) and 'mis' (mass) that became a loan word in English. Muslim groups use this word in their activities around the mosque. This example shows that Christian concepts from everyday religiosity in Europe can become the origin term for activities in which Muslims gather for a religious purpose.

22. See Diyanet's Recent Announcement on Exam Requirements for Male/Female Religious Officials Working Abroad (i.e., Outside of TURKEY) for a Longer Time. Document in Turkish. Available online: http://disiliskiler.diyanet.gov.tr/Documents/2018\%20Y\%C4\%B11\%C4\%B1\%20Yurtd\%C4\%B1\%C5\% 9F\%C4\%B1\%20Bay-Bayan\%20Din\%20G\%C3\%B6revlisi\%20S\%C4\%B1nav\%20Duyurusu (accessed on 11 December 2018).

23. Sözeri, S.; Altinyelken, H.; Volman, M. Training Imams in The Netherlands: The Failure of a Post-Secular endeavour. Br. J. Relig. Educ. 2018, 1-11. [CrossRef]

24. Öztürk, A.E.; Sözeri, S. Diyanet as a Turkish Foreign Policy Tool: Evidence from The Netherlands and Bulgaria. Polit. Relig. 2018, 11, 624-648. [CrossRef]

25. Yükleyen, A.; White, J.B. The European Market for Islam: Turkish Islamic Communities and Organizations in Germany and The Netherlands; Syracuse University Press: Syracuse, NY, USA, 2007.

26. Boender, W. Embedding Islam in the 'moral covenants' of European states: The case of a state-funded imam training in The Netherlands. J. Muslims Eur. 2013, 2, 227-247. [CrossRef]

27. Boender, W.; Kanmaz, M. Imams in The Netherlands and Islam Teachers in Flanders. In Intercultural Relations and Religious Authorities: Muslims in the European Union; Van Koningsveld, P.S., Shadid, W.A.R., Eds.; Peeters Publishers: Paris, France, 2002; pp. 169-180.

28. Ghaly, M.M.I. The academic training of imams: Recent discussions and initiatives in The Netherlands. In The Study of Religion and the Training of Muslim Clergy in Europe: Academic and Religious Freedom in the 21st Century; Drees, W., Koningsveld, P.S., Eds.; Amsterdam University Press: Amsterdam, The Netherlands, 2008; pp. 369-402. 
29. Boender, W. Dossier imamopleiding: Het Nederlandse 'imamopleidingsdebat' in historisch perspectief. Tijdschr. Relig. R. Beleid 2014, 5, 26-48. [CrossRef]

30. Roex, I.; van Stiphout, S.; Tillie, J. Salafisme in The Netherlands; Instituut voor Migratie- en Etnische Studies: Amsterdam, The Netherlands, 2010.

31. Kepel, G. The War for Muslim Minds; Harvard University Press: Boston, MA, USA, 2006.

32. Roy, O. Globalized Islam: The Search for the New Ummah; Hurst and Company: London, UK, 2004.

33. However, Olivier Roy [15] (p. 123) notes that compared to other Muslims, Turkish migrants tend to preserve their language and ethno-national identity.

34. De Koning, M. The Netherlands. In Yearbook of Muslims in Europe 5; Nielsen, J.S., Akgönül, S., Alibašić, A., Račius, E., Eds.; Brill: Boston, MA, USA, 2016; pp. 421-435.

35. Matthew Bowl; Benjamin van Impelen, The Imam Training Debate: The Future of Religion for Dutch Muslims. Available online: https:/www.humanityinaction.org/knowledgebase/190-the-imam-training-debate-thefuture-of-religion-for-dutch-muslims (accessed on 2 February 2019).

36. Rath, J.; Penninx, R.; Groenendijk, K.; Meyer, A. Western Europe and Its Islam; Brill: Leiden, The Netherlands, 2001.

37. Landman, N. Imams in The Netherlands: Home-Made Better than Import? ISIM Newsl. 1999, 2, 5.

38. Sunier, T.; Landman, N. Diyanet: The Turkish Directorate for Religious Affairs in a Changing Environment; VU/UU: Amsterdam/Utrecht, The Netherlands, 2011.

39. Sunier, T.; Landman, N. Transnational Turkish Islam; Springer: Berlin/Heidelberg, Germany, 2014.

40. As the Turkish name suggests, this school was originally founded to train government-employed imams after the abolition of madrasas in Turkey through the country's Unification of Education act.

41. These abbreviations refer to study tracks in Dutch secondary education: Preparatory middle-level vocational education (VMBO), higher general continued education (HAVO) and preparatory scholarly education (VWO).

42. AnadoluAjansı Hollanda Ile "Imam Hatip" Anlaşması. Available online: http://www.ntv.com.tr/egitim/ hollanda-ile-imam-hatip-anlasmasi,FcnysMZIPUejLaZTWqhI7Q?_ref=infinite (accessed on 23 April 2017).

43. Kasteleijn, N. 'Ibn Ghaldoun failliet verklaard—school was eerder al gesloten na inspectie' [Ibn Ghaldoun Declared Bankrupt-School Had Been Previously Closed After Inspection]. Nrc.nl, 8 October 2013. Available online: https://www.nrc.nl/nieuws/2013/10/08/ibn-ghaldoun-failliet-verklaard-a1430902 (accessed on 5 November 2016).

44. De Koning, M. The Netherlands. In Yearbook of Muslims in Europe 6; Nielsen, J.S., Akgönül, S., Alibašić, A., Račius, E., Eds.; Brill: Leiden, The Netherlands; Boston, MA, USA, 2015; pp. 439-458.

45. In September 2014, the Ibn Ghaldoun school was succeeded by the Avicenna College, a new Islamic secondary school with a new board of management.

46. Huijnk, W.; Dagevos, J. Dichter bij Elkaar? De Sociaal-Culturele Positie van Niet-Westerse Migranten in The Netherlands [Closer Together? The Socio-Cultural Position of Non-Western Migrants in The Netherlands]; Sociaal en Cultureel Planbureau: Den Haag, The Netherlands, 2012.

47. Kara, İ. Cumhuriyet Türkiyesi'nde Bir Mesele Olarak İslam 1 [Islam as a Matter in Republican Turkey 1]; Dergah Yayınları: İstanbul, Turkey, 2017.

48. Kara, İ. Cumhuriyet Türkiyesi'nde Bir Mesele Olarak İslam 2 [Islam as a Matter in Republican Turkey 2]; Dergah Yayınları: İstanbul, Turkey, 2017.

49. Lafleur, J. Why Do States Enfranchise Citizens Abroad? Comparative Insights from Mexico, Italy and Belgium. Glob. Netw. 2011, 11, 481-501. [CrossRef]

50. Laik is the Turkish translation of-And was inspired as a concept by-The French term laïcité.

51. Parla, T.; Davison, A. Secularism and laicism in Turkey. In Secularisms; Davison, A., Jacobsen, J.R., Pellegrini, A., Eds.; Duke University Press: Durham, UK, 2008.

52. Gözaydın, İ. Diyanet and politics. Muslim World 2008, 8, 216-227. [CrossRef]

53. Gözaydın, İ. Diyanet: Türkiye Cumhuriyeti'nde Dinin Tanzimi [Diyanet: Arranging Religion in the Turkish Republic]; İletişim Yayınları: İstanbul, Turkey, 2009.

54. Saatçi, M. Religious Conflict in the Periphery. Islam and Politics in Turkey. In Religious Innovation in a Global Age. Essays on the Construction of Spirituality; Lundskow, G., Ed.; McFarland \& Company: London, UK, 2005; pp. 228-246.

55. See the Interview with İsmail Kara for Similar Opinions (In Turkish): Diyanet Müslümanların Değil, Devletin Din İşlerine Bakar [Diyanet Is Not for Muslims But for the State]. Altınoluk. 1993, p. 93. Available online: https://dergi.altinoluk.com/index.php?sayfa=yillar\&MakaleNo=d093s022m1 (accessed on 12 May 2014). 
56. Hendric, B. Introduction-Beyond State Islam: Religiosity and Spirituality in Contemporary Turkey. Eur. J. Turk. Stud. 2011, 13, 1-16.

57. Gürlesin, Ö.F. Transformation of Friday sermons in an era of nationalism; functionalization of religion, now and in a challenged future. 2019, in press.

58. After the failed coup attempt on 15 July 2016 — directed against state institutions—the Turkish government dismissed many imams with governmental decrees.

59. Operation Olive Branch (Turkish: Zeytin Dalı Harekâtı) is an ongoing cross-border operation, executed by the Turkish Armed Forces and allied Syrian Arab and Turkish militias in the majority-Kurdish Afrin district of northwest Syria.

60. Schoonhoven, S. Jihadpreek in Hoorn. De Telegraaf. 7 February 2018. Available online: https://www. telegraaf.nl/nieuws/1681468/jihadpreek-in-hoorn (accessed on 19 July 2018).

61. Ziebertz, H.-G. Dispute about the Public Significance of Religion: An Opening Reflection. In The Public Significance of Religion: Empirical Studies in Theology; Francis, L.J., Ziebertz, H.-G., Eds.; Brill: Leiden, The Netherlands; Boston, MA, USA, 2011; pp. 1-18.

62. Ferreira, T.; Salgado, J.; Cunha, C. Ambiguity and the dialogical self: In search for a dialogical self. Estud. Psicol. 2006, 27, 19-32. [CrossRef]

63. Valsiner, J. Looking across cultural boundaries. Integr. Psychol. Behav. Sci. 2007, 41, 219-224. [CrossRef] [PubMed]

64. Yūnus Emre is an immensely popular Anatolian Turkish mystic poet of the second half of the 13th and the first quarter of the 14th century. Legend has it that one day a stern teacher named Molla Kāsım found a collection of Yūnus Emre's poetry. When he sat down by the river and began to read the poems, he found them contrary to his dogmatic religious understanding. He threw a 1000 poems into the river and a 1000 poems into the air. When Molla Kāsım came to the 2001st poem, he noticed that the couplet said: 'O Yūnus! Do not tell your words in a crooked way, or Molla Kāsım will come and straighten you'.

65. Gürlesin, Ö.F.; Ter Avest, I.; Alasağ, A.; Akdă̆, M. Playful Religious Education-Towards Inclusive Religious Education: A Light-Hearted Way for Young People to Develop a Religious Life Orientation. Submitted article to "Religions" 2018, 9, submitted for review.

66. Roof, W.C.; Wilson, B. Religion in sociological perspective. Contemp. Sociol. 1983, 12, 716. [CrossRef]

67. Güngör, Ö. Yaşlılık ve din [Aging and Religiosity]. In Din Sosyolojisi [Sociology of Religion]; Çapçıŏlu, İ., Akyüz, N., Eds.; Grafiker Yayınları: İstanbul, Turkey, 2012; pp. 253-267.

68. Karaşahin, H. Gençlik ve din [Youth and Religion]. In Din Sosyolojisi [Sociology of Religion]; Çapçıoğlu, İ., Akyüz, N., Eds.; Grafiker Yayınları: İstanbul, Turkey, 2012; pp. 237-252.

69. Hökelekli, H. Gençlik ve din [Youth and religion]. In Gençlik, Din ve Değerler Psikolojisi [Youth, Religion and Psychology of Ethics]; Hökelekli, H., Ed.; Dem Yayınları: İstanbul, Turkey, 2006; pp. 9-33.

70. Hökelekli, H. Çocuk, Genç, Aile Psikolojisi ve Din [CHILD, Youth, Family Psychology and Religion]; Dem Yayınları: İstanbul, Turkey, 2009.

71. Becker, J.; De Hart, J. Godsdienstige Veranderingen in The Netherlands; SCP: The Hague, The Netherlands, 2006.

72. Voor het Regeringsbeleid, W.R. Dynamiek in Islamitisch Activ-Isme: Aanknopingspunten Voor Democratisering en Mensenrechten; Amsterdam University Press: Amsterdam, The Netherlands, 2006.

73. Stark, R.; McCann, J.C. Market forces and catholic commitment: Exploring the new paradigm. J. Sci. Study Relig. 1993, 32, 111-124. [CrossRef]

74. Shadid, W.A.R.; van Koningsveld, P.S. Religious Authorities of Muslims in the West: Their Views on Political Participation. In Intercultural Relations and Religious Authorities: Muslims in the European Union; Shadid, W.A.R., van Koningsveld, P.S., Eds.; Peeters: Leuven, Belgium, 2002; pp. 149-170.

75. Gürlesin, Ö.F.; Avest, I.; Alasağ, A.; Akdağ, M. Religious voices in diaspora: An exploration of religious identity development of Dutch-Turkish Muslims. In Proceedings of the 2018 SocRel Annual Conference: Religion and Education, Glasgow, Scotland, 10-12 July 2018.

(C) 2019 by the author. Licensee MDPI, Basel, Switzerland. This article is an open access article distributed under the terms and conditions of the Creative Commons Attribution (CC BY) license (http://creativecommons.org/licenses/by/4.0/). 